\title{
Navigating Turbulent Religious Diversity in Global Health
}

\section{Annekathryn Goodman}

Division of Gynecologic Oncology, Department of Obstetrics and Gynecology, Massachusetts General Hospital, Harvard Medical School, Boston, MA, USA

Email: agoodman@mgh.harvard.edu

How to cite this paper: Goodman, A. (2018) Navigating Turbulent Religious Diversity in Global Health. Open Journal of Social Sciences, 6, 50-53.

https://doi.org/10.4236/jss.2018.610005

Received: September 13, 2018

Accepted: October 20, 2018

Published: October 23, 2018

Copyright $\odot 2018$ by author and Scientific Research Publishing Inc. This work is licensed under the Creative Commons Attribution International License (CC BY 4.0).

http://creativecommons.org/licenses/by/4.0/

\begin{abstract}
Physicians who work internationally and in culturally diverse settings will on occasion be challenged by political upheavals, riots, or other disturbances. Medical professionals who work in global health need to be aware of the tensions and challenges that people of different religions experience. This editorial reviews the philosophy of several theological leaders who grappled with issues of social justices and the importance of respectful communication and understanding across religious differences. Physicians must have training and develop expertise in global health diplomacy to function on three levels: individual, national, and international.
\end{abstract}

\section{Keywords}

Religious Difference, Religious Injustice, Interfaith Environment, Global Health Diplomacy

\section{Personal Experience}

In September of 2012 two colleagues and I were caught up in a crowd in Dhaka, Bangladesh. We were trying to get to the airport after two weeks of medical work in India and Bangladesh. The crowd was angry at America. They were burning an "American" straw figure and chanting. This all occurred two weeks after the start of anti-American riots in many Muslim countries on September 11 of 2012. An anti-Islamic movie trailer called "The Innocence of Muslims" which was downloaded onto YouTube in July triggered Muslim anger, riots, many injuries, and at least 50 deaths [1].

We ultimately left Bangladesh for the United States physically unscathed but emotionally rattled. This led me to want to understand the background to religious tensions, religious intolerance, and how that impacted the safety of inno- 
cent bystanders of different faiths.

\section{Commentary}

The ideal moment for communication must occur among leaders of different groups within a space of safety. Once a crowd has formed, it is very challenging to have a sober dialogue and to address grievances. The raw emotions of anger and hatred fuel a mob to violence and destruction. Two Jewish theologians, Rabbi Abraham Joshua Heschel and Rabbi Joseph Soloveitchik, devoted their lives to peaceful confrontation of injustices and communication between groups that are either separated by religion or by race. The teachings of these men are useful to examine and provide working tools for people who are working in foreign countries and among different religions.

Heschel stated that man's destiny is to serve and to aid [2]. This is very true for medical professionals. While healthcare providers will want to focus on health and illness, they may have to confront to consequences of political and religious injustices such as radicalized individuals and acts of violence. Heschel says the "man has to understand in order to believe and to know in order to accept" [3]. The violent Muslim reactions to trivial and artistically unimportant expressions such as "The Innocence of Muslims" reflect a deep sense of being victims of injustice, oppression, and the disrespect of Islam [4].

How can a dialogue be developed to address to issues of injustices done to one group and to foster respect and tolerance of all religions? Soloveitchik examined this issue in his essay "Confrontation" [5]. He examined the survival of a small minority religion such as Judaism, surrounded by a large Christian culture. He stated that the first element needed to allow an interfaith environment is the acknowledgement of the existence of the other person and the other faith. The tensions over accepting the existence of another faith develop out of the natural human tendency to dominate and have power over another group and the fear of being existentially obliterated by the dominant religious power. Soloveitchik stated, "There is no identity without uniqueness." As result, he concludes that interfaith acceptance does not occur from finding common ground between different religions. He continued that true conscious acknowledgement or "confrontation" between two faith communities requires assurance that both groups have equal rights and full religious freedom. The four requirements for peaceful coexistence demand an acknowledgement and understanding that: 1) each group has an independent faith community, 2) the creed of a community cannot be universalized to other religious groups, 3) groups should not try to suggest changes in texts and rituals of another group, 4) each group must be free to express their fervent beliefs [5].

While Soloveitchik fought for the survival of the minority religion demanding confrontation with the dominant religion, Heschel taught about the importance of spiritual community and regard. He stressed the need for connectedness and respect among different religions [3]. He examined the tension of faith with lack 
of faith and felt that lack of faith or nihilism was the biggest threat to humanity. He stressed the commonalities among people of different faiths, which is the kinship of being human. The danger was less about one religion obliterating another than about the lack of moral grounding annihilating humanity.

Heschel outlines four dimensions of religious experience that are important for members of different faiths to incorporate in their dialogues with each other: 1) The creed and doctrine, 2) Faith and inward intimacy of religious belief, 3) The sacred acts of religion, 4) The context of religion with reference to community, history, and covenant. Heschel envisioned the basis of meeting with other groups as an acknowledgement that all religious traditions are pathways with which to reach God and are all means to an end. He admonished that people in dialogue with each other must have "fear and trembling," and "humility and contrition" [2]. He felt that respect, love of each other, and indebtedness to each other will allow an interfaith environment to flourish.

Another leader and visionary, Reverend Martin Luther King, Jr., also stressed the importance of faith in building unity and bringing peace where there was injustice. He preached, "With this faith, we will be able to transform the jangling discords of our nation into a beautiful symphony of brotherhood. With this faith, we will be able to work together, to struggle together, to stand up for freedom together, knowing that we will be free one day." [6].

The lessons from these great theologians include acknowledging the importance and uniqueness of each great religion. The interfaith environment is nurtured not by finding common ground in theology but by finding common ground in humanity, respect and understanding. Reverend King added the important element of pushing back against injustice, not by violence but by faith and unity.

\section{Conclusion}

Medical professionals who work in global health need to be aware of the tensions and challenges that people of different religions experience. Citizens of resource poor countries may explain perceived injustices in relation to their religion and how the public media of the United States portrays them. Physicians must also be diplomats to work effectively in these complex environments [7]. Cultural competency should be part of medical training for those who work internationally [8]. Global health diplomacy (GHD) should function on three levels: individual, domestic/national, and global/international [9]. Nursing training should also involve respectful acceptance of beliefs of others [10]. Finally GHD practitioners should receive training to successfully negotiate the intersection of global health and foreign affairs [11]. Our goal must be to treat individuals and institutions with reverent respect and to identify our common humanity and our common goals to alleviate suffering.

\section{Conflicts of Interest}

The author declares no conflicts of interest regarding the publication of this paper. 


\section{References}

[1] Flock, E. (2012) How 'Innocence of Muslims' Spread around the World and Killed a US Diplomat. US News and Report.

http://www.usnews.com/news/articles/2012/09/12/how-innocence-of-muslims-spre ad-around-the-globe-and-killed-a-us-diplomat

[2] Heschel, A.J. (2011) Our Destiny Is to Aid. In: Heschel, S., Ed., Abraham Joshua Heschel; Essential Writings, Orbis Books, Maryknoll, New York, 189.

[3] Heschel, A.J. (2011) No Religion Is an Island. In: Heschel, S., Ed., Abraham Joshua Heschel: Essential Writings, Orbis Books, Maryknoll, New York, 116-136.

[4] Esposito, J.L. (2002) Unholy War; Terror in the Name of Islam. Oxford University Press, Oxford.

[5] Soloveitchik, J.B. (1964) Confrontation Tradition. Journal of Orthodox Thought, 6, $1-14$.

[6] King, M.L. (1963) "I Have a Dream.." https://www.archives.gov/files/press/exhibits/dream-speech.pdf

[7] Gagnon, M.L. and Labonté, R. (2013) Understanding How and Why Health Is Integrated into Foreign Policy-A Case Study of Health Is Global, a UK Government Strategy 2008-2013. Globalization and Health, 9, 24. https://doi.org/10.1186/1744-8603-9-24

[8] Mews, C., Schuster, S., Vajda, C., Lindtner-Rudolph, H., Schmidt, L.E., Bösner, S. and Knipper, M. (2018) Cultural Competence and Global Health: Perspectives for Medical Education. Position Paper of the GMA Committee on Cultural Competence and Global Health. GMS Journal for Medical Education, 35, Doc28.

[9] Ruckert, A., Labonté, R., Lencucha, R., Runnels, V. and Gagnon, M. (2016) Global Health Diplomacy: A Critical Review of the Literature. Social Science \& Medicine, 155, 61-72. https://doi.org/10.1016/j.socscimed.2016.03.004

[10] Wilson, D., Heaslip, V. and Jackson, D. (2018) Improving Equity and Cultural Responsiveness with Marginalised Communities: Understanding Competing Worldviews. Journal of Clinical Nursing, 27, 3810-3819.

https://doi.org/10.1111/jocn.14546

[11] Brown, M.D., Bergmann, J.N., Novotny, T.E. and Mackey, T.K. (2018) Applied Global Health Diplomacy: Profile of Health Diplomats Accredited to the UNITED STATES and Foreign Governments. Globalization and Health, 14, 2. https://doi.org/10.1186/s12992-017-0316-7 